\title{
PENGARUH CUSTOMER EXPERIENCE TERHADAP REVISIT INTENTION PADA PAKET WISATA SEPEDA DI DESA PENGLIPURAN
}

\author{
Ni Wayan Setyaningsih ${ }^{1}$, I Wayan Suardana ${ }^{2}$, LGLK. Dewi ${ }^{3}$ \\ ${ }^{1}$ Email: wayansetyaningsih64@gmail.com \\ Program Studi Industri Perjalanan Wisata, Fakultas Pariwisata, Universitas Udayana \\ ${ }^{2}$ Email: suar.dana@yahoo.co.id \\ Program Studi Industri Perjalanan Wisata, Fakultas Pariwisata, Universitas Udayana \\ ${ }^{3}$ Email: leli_ipw@unud.ac.id \\ Program Studi Industri Perjalanan Wisata, Fakultas Pariwisata, Universitas Udayana
}

\begin{abstract}
Customer experience is one of the strategies created at the moment of truth that has a longterm impact on subsequent visiting decisions. Interest in revisiting in this study is called revisit intention, defined as the possibility of tourists to repeat activities or revisit a tourist attraction. This research was conducted to determine the effect of customer experience to the revisit intention of the domestic tourists of bicycle tour package users "Fun-Tastic Shuttle Bike Adventures" in Penglipuran Village. The technique of determining sample using purposive sampling technique by distributed 135 questionnaires to the domestic tourists who used bicycle tour packages "Fun-Tastic Shuttle Bike Adventures" as the respondents. Data collected by using questionnaires with Likert Scale and calibrated by using the validity test and reliability test to find coefficient Alpha Cronbach 0,6. The technique of data analysis used multiple linear regression analysis. Based on the calculation of PASW Statictic 18 (Powerful Statistic Software Application), the results indicate that there is no significant effect of customer experience to revisit intention on the bicycle tour package "Fun-Tastic Shuttle Bike Adventures" in Penglipuran Village.
\end{abstract}

Abstrak: Customer experience merupakan salah satu strategi yang diciptakan pada saat moment of truth yang dapat berdampak jangka panjang terhadap keputusan berkunjung selanjutnya. Minat berkunjung ulang dalam penelitian ini disebut dengan revisit intention, didefinisikan sebagai kemungkinan wisatawan untuk mengulangi aktivitas atau berkunjung ulang ke suatu daya tarik wisata. Penelitian ini dilakukan untuk mengetahui pengaruh customer experience terhadap revisit intention wisatawan nusantara pengguna paket wisata sepeda "Fun-Tastic Shuttle Bike Adventures" di Desa Penglipuran. Teknik penentuan sampel menggunakan teknik purposive sampling dengan membagikan 135 kuisioner kepada wisatawan nusantara yang menggunakan paket wisata sepeda "Fun-Tastic Shuttle Bike Adventures". Data dikumpulkan dengan menggunakan kuisioner model skala likert yang dikalibrasikan dengan memakai uji validitas dan uji reliabilitas dihitung dengan memakai koefisien Alpha Cronbach 0, 6. Teknik analisis data dalam penelitian ini menggunakan teknik analisis regresi linear berganda. Berdasarkan perhitungan perangkat lunak PASW Statictic 18 (Powerful Statistic Software Application) diperoleh hasil bahwa tidak terdapat pengaruh yang signifikan customer experience terhadap revisit intention pada paket wisata sepeda "Fun-Tastic Shuttle Bike Adventures" di Desa Penglipuran.

Keywords: customer experience, penglipuran, revisit intention.

\section{PENDAHULUAN}

Bali sebagai destinasi wisata terpopuler merupakan ikon pariwisata Indonesia yang terkenal hingga ke mancanegara. Berdasarkan data Badan Pusat Statistik Indonesia, jumlah kunjungan wisatawan ke Indonesia pada tahun
2018 sebesar 15,81 juta wisatawan, destinasi wisata Bali berkontribusi lebih dari $25 \%$ terhadap Indonesia sebagai sebuah negara yang terbilang besar. Bali memiliki atraksi wisata yang dapat menarik banyak wisatawan baik itu wisatawan nusantara ataupun 
mancanegara. Provinsi Bali terbagi menjadi 8 kabupaten dan 1 kota yang menyebabkan potensi wisata yang ada tersebar ke 9 wilayah tersebut. Kabupaten Bangli merupakan salah satu Kabupaten di Bali dengan luas wilayah $490,71 \mathrm{~km}^{2}$, terletak di bagian tengah pulau Bali. Secara administratif Kabupaten Bangli terdiri dari 4 Kecamatan, 4 Kelurahan dan 65 Desa. Kabupaten Bangli merupakan satusatunya kabupaten di Bali yang tidak memiliki wilayah pantai/laut, namun kabupaten Bangli menyimpan sejumlah potensi menjanjikan seperti keindahan Danau Batur dan Gunung Batur serta beberapa atraksi wisata lainnya.

Desa Penglipuran adalah salah satu desa wisata budaya yang diminati di Kabupaten Bangli dan merupakan desa wisata yang pertama kali ditetapkan di Kabupaten Bangli. Desa ini ditetapkan sebagai daya tarik wisata pada tahun 1993. Hal tersebut didasari karena ada banyak potensi daya tarik wisata dan prestasi yang dimiliki oleh Desa Adat Penglipuran, Pemerintah Daerah Tingkat II Bangli mengeluarkan Surat Keputusan (SK) Bupati Daerah Tingkat II Bangli No. 115 tanggal 29 April 1993, yang menetapkan Desa Penglipuran sebagai daya tarik wisata atau sebagai daerah kunjungan para wisatawan. Sejak ditetapkan sebagai daya tarik wisata, Desa Penglipuran telah mendapatkan beberapa penghargaan diantaranya berupa Kalpataru pada tahun 1995, sebagai Green Gold Kategori Budaya dalam Indonesia Sustainable Tourism Award (ISTA) 2017 dan sebagai desa terbersih di dunia bersama desa di India dan Belanda pada tahun 2016.

Desa Penglipuran ramai dikunjungi wisatawan karena memiliki potensi yang dapat dikembangkan menjadi atraksi wisata atau daya tarik wisata. Dalam perkembangannya hingga saat ini, potensi wisata di Desa Penglipuran belum digali secara maksimal. Sampai saat ini wisatawan yang datang berkunjung hanya berjalan-jalan menikmati keindahan rumah penduduk yang tersusun rapi, mengunjungi hutan bambu dan Taman Makam Pahlawan sebagai daya tarik wisata Desa Penglipuran tanpa melakukan aktivitas wisata lainnya. Hal ini dikhawatirkan membuat kunjungan wisatawan menurun serta rendahnya minat wisatawan untuk berkunjung kembali (revisit intention).

Di Bali, khususnya kabupaten Bangli terjadi pengembangan daya tarik wisata yang semakin beragam. Fenomena ini memberikan banyak alternatif pilihan bagi wisatawan dalam berwisata yang menyebabkan wisatawan cenderung melakukan kunjungan ke berbeda destinasi untuk merasakan pengalaman yang baru. Maka dari itu, tingkat keputusan berkunjung dan revisit intention atau niat berkunjung kembali wisatawan di beberapa destinasi tidak stabil. Untuk mengetahui sejauh mana minat wisatawan untuk berkunjung kembali ke daya tarik wisata Desa Penglipuran, maka dilakukan prapenelitian dengan menyebar kuesioner mengenai revisit intention kepada 83 wisatawan pada tanggal 24 November 2018. Hasil pra-penelitian revisit intention wisatawan yang berkunjung ke Desa Penglipuran, menunjukkan bahwa hanya 25 orang (30\%) yang memiliki niat untuk berkunjung kembali ke Desa Penglipuran, sisanya sejumlah 58 orang (70\%) mengatakan tidak berniat berkunjung kembali ke Desa Penglipuran.

Besarnya persentase ketidakinginan wisatawan untuk berkunjung kembali ke Desa Penglipuran didasari oleh beberapa faktor seperti kesan wisatawan saat berkunjung, kepuasan wisatawan serta pengalaman yang didapatkan saat mengunjungi daya tarik wisata. Melihat permasalahan yang terjadi maka perlu adanya penyelesaian, karena dampak dari sedikitnya niat wisatawan untuk berkunjung kembali akan berdampak pula pada tingkat kunjungan wisatawan di masa mendatang pun akan terus menurun. Pengelola harus mencanangkan strategi sebagai upaya dalam proses penciptaan revisit intention, dimana dalam proses tersebut terdapat tahapan yang harus di tempuh pengelola maupun konsumennya sendiri.

Berdasakan fenomena tersebut, maka dilakukan eksperimen pengadaan atraksi wisata berupa paket wisata sepeda yang bernama "Fun-Tastic Shuttle Bike Adventures". Paket wisata sepeda ini merupakan optimalisasi pengembangan potensi wisata yang ada di Desa Penglipuran, berupa kegiatan bersepeda guna menikmati keindahan sekitar area wisata Desa Penglipuran dengan ditemani pemandu wisata lokal yang siap mengantarkan ke spot-spot terbaik serta memberikan informasi yang dibutuhkan wisatawan (right information for free). Rute yang ditawarkan untuk wisata sepeda ini adalah jalan melingkar di Desa Penglipuran yang juga melewati spot-spot 
menarik seperti hutan bambu dan Taman Makam Pahlawan. Paket wisata sepeda ini juga dilengkapi dengan fasilitas berupa sepeda serta kelengkapannya, pemandu wisata lokal, serta minuman dan kue khas Desa Penglipuran. Eksperimen paket wisata sepeda ini ditawarkan kepada wisatawan nusantara dengan tujuan untuk mengetahui gambaran customer experience yang didapatkan wisatawan serta pengaruhnya terhadap niat untuk berkunjung kembali.

Secara umum, customer experience merupakan salah satu strategi yang diciptakan pada saat moment of truth, yaitu ketika proses pembelian dilakukan oleh konsumen yang dapat berdampak jangka panjang terhadap keputusan berkunjung selanjutnya. Minat berkunjung ulang disebut dengan revisit intention atau minat untuk kembali berkunjung, didefinisikan sebagai kemungkinan wisatawan untuk mengulangi aktivitas atau berkunjung ulang ke suatu daya tarik wisata (Baker dan Crompton dalam Chung-Hslen Lin (2012)). Sesuai dengan pengertian tersebut maka eksperimen paket wisata sepeda "Fun-Tastic Shuttle Bike Adventures" ini memfokuskan pengalaman wisatawan dengan customer experience wisatawan yang berkunjung. Dengan customer experience yang dirasakan wisatawan yang berkunjung diharapkan dapat meningkatkan revisit intention para wisatawan ke Desa Penglipuran.

Berdasarkan latar belakang yang telah dipaparkan, pernyataan serta fenomena di atas, maka penelitian ini perlu dilakukan guna mengetahui pengaruh customer experience terhadap revisit intention pada eksperimen paket wisata sepeda "Fun-Tastic Shuttle Bike Adventures" di Desa Penglipuran.

\section{METODE}

Penelitian ini dilakukan untuk mengukur dan mengetahui pengaruh customer experience terhadap revisit intention pada paket wisata sepeda "Fun-Tastic Shuttle Bike Adventures" di Desa Penglipuran.

Adapun variabel yang digunakan adalah variabel Customer Experience (X) dan variabel Revisit Intention (Y). Customer experience merupakan pengalaman yang didapatkan oleh konsumen baik itu secara langsung maupun tidak langsung mengenai proses pelayanan, pengelolaan, fasilitasfasilitas, dan bagaimana cara seorang konsumen berinteraksi dengan pengelola dan dengan konsumen lainya. Variabel customer experience terdiri dari 8 dimensi yaitu dimensi comfort, dimensi educational, dimensi hedonic, dimensi novelty, dimensi recognized, dimensi relational, dimensi safety dan dimensi beauty. Selanjutnya revisit intention merupakan kemungkinan wisatawan utnuk mengulangi aktivitas atau berkunjung ulang ke suatu destinasi (Baker dan Crompton dalam Chung Hslen Lin, 2012).

Pengumpulan data dengan menggunakan kuisioner yang dibagikan kepada wisatawan nusantara pengguna paket wisata sepeda "Fun-Tastic Shuttle Bike Adventures" di Desa Penglipuran. Kuisioner yang digunakan adalah kuisioner tipe pilihan, dimana wisatawan dapat memilih jawaban dari beberapa pilihan yang merupakan data kualitatif yang diberi skor. Pemberian skor berdasarkan pada skala likert, dimana skor 1 menyatakan sangat tidak baik, skor 2 menyatakan tidak baik, skor 3 menyatakan cukup baik, skor 4 menyatakan baik dan skor 5 menyatakan sangat baik (Ridwan MBA dalam Ardana, 2016).

Untuk mengukur sampel, peneliti menggunakan teknik penentuan sampel menurut Hair et al, 1995 (dalam Kiswanti, 2010) yang menyatakan bahwa sampel yang representatif adalah tergantung pada jumlah indikator dikali 5 sampai 10. Berdasarkan teknik tersebut, jumlah sampel untuk mengukur pengaruh customer experience terhadap revisit intention adalah sebesar 135 orang wisatawan nusantara.

Teknik analisis data yang digunakan adalah teknik analisis data statistika deskriptif. Statistika deskriptif berfungsi untuk menerangkan keadaan, gejala, atau persoalan. Penarikan kesimpulan pada statistika deskriptif adalah statistik yang digunakan untuk menganalisa data dengan cara mendeskripsikan atau menggambarkan data yang telah terkumpul sebagaimana adanya tanpa bermaksud membuat kesimpulan belaka untuk umum atau generalisasi. Penelitian ini dianalisis dengan menggunakan PASW 18.0 (Powerful Statistic Software Application) for windows guna memaparkan data dari kuisioner yang diperoleh peneliti. Analisis statistik yang dilakukan berupa uji validitas, uji reliabilitas, uji signifikan secara parsial (Uji t) dan uji signifikan secara simultan (uji F) untuk 
hipotesis, analisis linier berganda, dan analisis koefisien determinasi.

\section{HASIL DAN PEMBAHASAN}

Desa Penglipuran terletak di wilayah Kelurahan Kubu, Kecamatan Bangli, Kabupaten Bangli, Provinsi Bali. Desa Penglipuran berada pada jarak sekitar $45 \mathrm{~km}$ dari Kota Denpasar dan sekitar $5 \mathrm{~km}$ dari Ibu Kota Kabupaten Bangli. Desa Penglipuran merupakan salah satu kawasan pedesaan di Bali yang memiliki tatanan yang teratur dari struktur desa tradisional, perpaduan tatanan tradisional dengan banyak ruang terbuka pertamanan yang asri menciptakan nuansa Bali pada zaman dahulu kala. Penataan fisik dan struktur desa, tidak lepas dari budaya yang dipegang teguh oleh masyarakat adat Desa Penglipuran secara turun-temurun. Desa Penglipuran memiliki berbagai potensi wisata yang menjadi daya tarik wisatawan untuk berkunjung. Daya tarik wisata yang dimiliki adalah pola tata ruang desa, arsitektur tradisional rumah penduduk, hutan bambu dengan beragam jenis bambu di dalamnya, adat istiadat masyarakat lokal, makanan dan minuman tradisional serta hasil kerajinan bambu khas Desa Penglipuran. Pola tata ruang desa yang menjadi daya tarik wisata di Desa Penglipuran adalah pada kawasan pemukiman penduduk berupa bagian depan rumah yang serupa dan seragam dari ujung utama desa sampai bagian hilir desa. Kawasan pemukiman penduduk tersusun sedemikian rapinya berjejer dari Utara ke Selatan yang terbagi ke dalam 2 bagian yaitu bagian Barat dan bagian Timur. Daerah utamanya lebih tinggi dan semakin menurun sampai ke daerah hilir. Selain memiliki keseragaman bentuk pada bagian depan rumah penduduk, terdapat pula keseragaman dari material yang digunakan untuk membangun berupa tanah paras untuk tembok dan bambu untuk atap.

Desa Penglipuran saat ini dikenal sebagai daya tarik wisata terbersih di dunia, dengan penataan ruang berlandaskan konsep Tri Mandala dan pengembangan pariwisata berbasis Tri Hita Karana. Desa Penglipuran merupakan desa adat yang telah dikembangkan sebagai daya tarik wisata unggulan di Kabupaten Bangli. Keunikan dan kekentalan budaya dan tradisi menjadikan desa wisata Penglipuran selalu ramai dikunjungi wisatawan baik wisatawan nusantara maupun wisatawan mancanegara, terutama pada hari libur dan perayaan hari-hari tertentu lainnya. Wisatawan yang datang dapat menikmati indahnya pemandangan desa dengan berjalan kaki di area desa. Desa Penglipuran merupakan desa wisata yang pertama kali ditetapkan di Kabupaten Bangli sebagai desa wisata budaya pada tahun 1993. Hal tersebut didasari karena ada banyak potensi daya tarik wisata dan prestasi yang dimiliki oleh Desa Adat Penglipuran, Pemda Tingkat II Bangli mengeluarkan Surat Keputusan (SK) Bupati Daerah Tingkat II Bangli No. 115 tanggal 29 April 1993, yang menetapkan Desa Penglipuran sebagai daya tarik wisata atau sebagai daerah kunjungan para wisatawan. Sejak ditetapkan sebagai daya tarik wisata, Desa Penglipuran telah mendapatkan beberapa penghargaan diantaranya berupa Kalpataru pada tahun 1995, sebagai Green Gold Kategori Budaya dalam Indonesia Sustainable Tourism Award (ISTA) 2017 dan sebagai desa terbersih di dunia bersama desa di India dan Belanda pada tahun 2016. Beberapa penghargaan ini juga berimbas terhadap perkembangan pariwisata di Desa Penglipuran.

Sejak dikembangkan sebagai daya tarik wisata sampai saat ini, wisatawan yang berkunjung ke Desa Penglipuran hanya melakukan aktivitas berjalan kaki menikmati keindahan daya tarik utama Desa Penglipuran berupa pola tata ruang pada kawasan pemukiman penduduk. Padahal Desa Penglipuran memiliki potensi daya tarik wisata lainnya seperti hutan bambu yang terletak di sebelah Utara desa dan Taman Makam Pahlawan yang terletak di sebelah Selatan desa. Kegiatan wisatawan yang datang hanya sebatas berjalan-jalan, mengambil gambar, kemudian pulang. Berdasakan hal tersebut paket wisata sepeda Fun-Tastic Shuttle Bike Adventures hadir sebagai sarana bagi wisatawan untuk lebih menikmati kegiatan wisatanya di Desa Penglipuran. Fun-Tastic Shuttle Bike Adventures adalah kegiatan wisata sepeda untuk menikmati keindahan alam Desa Penglipuran secara ramah lingkungan. Paket wisata sepeda ini disediakan untuk wisatawan guna menikmati keindahan sekitar area wisata Desa Penglipuran dengan ditemani pemandu wisata lokal yang siap mengantarkan ke spotspot terbaik serta memberikan informasi yang dibutuhkan wisatawan (right information for free).

Rute yang ditawarkan untuk wisata sepeda ini adalah jalan melingkar di Desa 
Penglipuran yang juga melewati beberapa spot-spot menarik seperti hutan bambu (bamboo forest) dan Taman Makam Pahlawan (hero monument). Waktu yang dibutuhkan untuk menikmati wisata sepeda ini adalah sekitar $1-2$ jam. Berikut ini adalah beberapa daya tarik wisata yang dikunjungi dalam paket wisata sepeda Fun-Tastic Shuttle Bike Adventures:

1. Hutan Bambu (Bamboo Forest)

Hutan bambu adalah jantung dari Desa Penglipuran, pemasok air bersih, bahan baku penting bagi bangunan tradisional seperti angkul-angkul (pintu masuk rumah) serta dapur dan juga sebagai produsen oksigen. Hutan bambu dengan luas sekitar 45 ha ini ditata dengan sangat rapi dengan berbagai jenis bambu di dalamnya. Keindahan hutan bambu ini dapat dinikmati oleh wisatawan yang berkunjung dengan menyusuri jalan setapak yang terdapat di sepanjang area hutan bambu. Jalan yang memecah kerimbunan hutan menjadi salah satu spot foto terbaik bagi wisatawan yang berkunjung.

2. Taman Makam Pahlawan (Hero Monument)

Menyusuri jalan utama desa ke arah Selatan terdapat sebuah kawasan suci yang didalamnya terdapat tugu pahlawan yang tertata dengan rapi. Taman Makam Pahlawan ini dibangun untuk memperingati serta mengenang jasa kepahlawanan Anak Agung Gede Anom Mudita atau yang lebih dikenal dengan nama Kapten Mudita yang merupakan pahlawan dari Kabupaten Bangli. Anak Agung Gede Anom Mudita, gugur melawan penjajah Belanda pada tanggal 20 November 1947. Taman Pahlawan ini dibangun oleh pemerintah kabupaten Bangli sebagai wujud bakti dan hormat mereka kepada sang pejuang. Selain sebagai taman penghormatan kepada pahlawan, saat ini Taman Makam Pahlawan ini juga merupakan daya tarik wisata di Desa Penglipuran.

\section{Frekuensi Persepsi Wisatawan terhadap Variabel Customer Experience dan Variabel Revisit Intention}

Berdasarkan hasil pengumpulan data, diperoleh rekapitulasi tanggapan wisatawan terhadap variabel customer experience dan variabel revisit intention yang menunjukkan bahwa dimensi relational memperoleh skor rata-rata paling tinggi yaitu sebesar 4,26 dan berada dalam kategori sangat baik. Sedangkan rata-rata skor dimensi lainnya yaitu dimensi comfort sebesar 3,83, dimensi educational sebesar 3,74, dimensi hedonic sebesar 4,02, dimensi novelty sebesar 3,71, dimensi recognized sebesar 4,19, dimensi safety sebesar 3,41, dimensi beauty sebesar 3,67 dan variabel revisit intention sebesar 4,10 berada pada kategori baik.

\section{Analisis Regresi Linear Berganda}

Analisis regresi berganda merupakan satu analisis peramalan nilai pengaruh dua atau lebih variabel bebas (X) terhadap variabel terikat (Y) untuk membuktikan ada atau tidaknya hubungan kausal antara dua variabel bebas atau lebih. Dalam penelitian ini analisis regresi linear berganda digunakan untuk mengukur pengaruh variabel comfort $\left(X_{1}\right)$, educational $\left(X_{2}\right)$, hedonic $\left(X_{3}\right)$, novelty $\left(X_{4}\right)$, recognized $\left(X_{5}\right)$, relational $\left(X_{6}\right)$, safety $\left(X_{7}\right)$, dan beauty $\left(X_{8}\right)$ terhadap revisit intention $(\mathrm{Y})$. Hasil analisis dinyatakan dengan persamaan regresi sebagai berikut:

$\mathrm{Y}=10,816+0,050 \mathrm{X}_{1}+0,023 \mathrm{X}_{2}+0,002 \mathrm{X}_{3}+$ $0,147 \mathrm{X}_{4}+(-0,012) \mathrm{X}_{5}+(-0,016) \mathrm{X}_{6+}(-0,044)$ $\mathrm{X}_{7}+(-0,019) \mathrm{X}_{8}$

Persamaan regresi berganda tersebut dapat dijelaskan sebagai berikut:

3. Nilai konstanta adalah sebesar 10,816 berarti jika semua variabel bebas memiliki nilai nol (0), maka nilai variabel terikat adalah sebesar 10,816. Dengan kata lain, variabel revisit intention $(\mathrm{Y})$ tetap sebesar 10,816 tanpa adanya pengaruh dari variabel bebas yaitu comfort $\left(\mathrm{X}_{1}\right)$, educational $\left(\mathrm{X}_{2}\right)$, hedonic $\left(\mathrm{X}_{3}\right)$, novelty $\left(\mathrm{X}_{4}\right)$, recognized $\left(\mathrm{X}_{5}\right)$, relational $\left(\mathrm{X}_{6}\right)$, safety $\left(\mathrm{X}_{7}\right)$ dan beauty $\left(\mathrm{X}_{8}\right)$.

4. Dimensi comfort $\left(\mathrm{X}_{1}\right)$ mempunyai koefisien regresi positif dengan nilai 0,050. Hal ini berarti setiap kenaikan dimensi comfort satu satuan dan variabel bebas yang lain konstan, maka mengakibatkan kenaikan variabel revisit intention $(\mathrm{Y})$ sebesar 0,050 .

5. Dimensi educational $\left(\mathrm{X}_{2}\right)$ mempunyai koefisien regresi positif dengan nilai 0,023. Hal ini berarti setiap kenaikan dimensi educational satu satuan dan 
variabel bebas yang lain konstan, maka mengakibatkan kenaikan variabel revisit intention (Y) sebesar 0,023 .

6. Dimensi hedonic $\left(\mathrm{X}_{3}\right)$ mempunyai koefisien regresi positif dengan nilai 0,002 . Hal ini berarti setiap kenaikan dimensi hedonic satu satuan dan variabel bebas yang lain konstan, maka mengakibatkan kenaikan variabel revisit intention $(\mathrm{Y})$ sebesar 0,002 .

7. Dimensi novelty $\left(\mathrm{X}_{4}\right)$ mempunyai koefisien regresi positif dengan nilai 0,147 . Hal ini berarti setiap kenaikan dimensi novelty satu satuan dan variabel bebas yang lain konstan, maka mengakibatkan kenaikan variabel revisit intention (Y) sebesar 0,147.

8. Dimensi recognized $\left(\mathrm{X}_{5}\right)$ mempunyai koefisien regresi negatif dengan nilai sebesar -0,012. Hal ini berarti setiap kenaikan dimensi recognized satu satuan dan variabel bebas yang lain konstan, maka mengakibatkan penurunan variabel revisit intention $(\mathrm{Y})$ sebesar 0,012 .

9. Dimensi relational $\left(\mathrm{X}_{6}\right)$ mempunyai koefisien regresi negatif dengan nilai sebesar -0,016. Hal ini berarti setiap kenaikan dimensi relational satu satuan dan variabel bebas yang lain konstan, maka mengakibatkan penurunan variabel revisit intention $(\mathrm{Y})$ sebesar 0,016 .

10. Dimensi safety $\left(\mathrm{X}_{7}\right)$ mempunyai koefisien regresi negatif dengan nilai $-0,044$. Hal ini berarti setiap kenaikan dimensi safety satu satuan dan variabel bebas yang lain konstan, maka mengakibatkan penurunan variabel revisit intention (Y) sebesar 0,044 .

11. Dimensi beauty $\left(\mathrm{X}_{8}\right)$ mempunyai koefisien regresi negatif dengan nilai $-0,019$. Hal ini berarti setiap kenaikan dimensi beauty satu satuan dan variabel bebas yang lain konstan, maka mengakibatkan penuruan variabel revisit intention (Y) sebesar 0,019 .

\section{Analisis Korelasi dan Koefisien Determinasi}

Analisis korelasi digunakan untuk mengetahui hubungan antara variabel bebas dengan variabel terikat secara bersama-sama. Dalam penelitian ini analisis korelasi dilakukan untuk mengukur hubungan secara simultan antara variabel comfort, educational, hedonic, novelty, recognized, relational, safety dan beauty terhadap variabel revisit intention.
Sedangkan koefisien determinasi $\left(\mathrm{R}^{2}\right)$ pada intinya mengukur seberapa jauh kemampuan model dalam menerangkan variasi variabel dependen. Nilai $\mathrm{R}^{2}$ yang kecil menunjukkan bahwa kemampuan variabel independen dalam menjelaskan variabel terikat amat sangat terbatas. Nilai yang mendekati satu menunjukkan variabel independen memberikan hampir semua informasi yang dibutuhkan untuk memprediksi variasi variabel dependen. Berikut ini adalah hasil analisis korelasi dan koefisien determinasi dalam penelitian ini.

Korelasi secara simultan variabel comfort, educational, hedonic, novelty, recognized, relational, safety dan beauty terhadap variabel revisit intention adalah sebesar 0,420 dan keeratan hubungan antar variabel ini berada pada interval kategori lemah dengan arah positif. Hal ini berarti apabila nilai comfort, educational, hedonic, novelty, recognized, relational, safety dan beauty meningkat maka akan meningkatkan revisit intention. Sebaliknya apabila nilai comfort, educational, hedonic, novelty, recognized, relational, safety dan beauty menurun maka revisit intention juga mengalami penurunan. Selanjutnya, dapat diketahui bahwa nilai dari koefisien determinasi atau $R$ Square adalah sebesar 0,176 . Hal ini menunjukkan bahwa kontribusi sumbangan secara simultan hubungan antara variabel comfort, educational, hedonic, novelty, recognized, relational, safety dan beauty terhadap revisit intention adalah 17,6\% sedangkan sisanya sebesar $82,4 \%$ dipengaruhi oleh faktor lain yang tidak diteliti dalam penelitian ini. Hal ini diperkuat oleh hasil penelitian dari Agung Edy Wibowo (2017), yang menyatakan hasil analisis bahwa sebesar $75,5 \%$, revisit intention dijelaskan oleh variabel service quality dan customer satisfaction.

\section{Uji t (Uji Parsial)}

Uji t pada dasarnya menunjukkan seberapa jauh pengaruh variabel bebas secara parsial dalam menerangkan variabel terikat. Dalam penelitian ini, Uji t digunakan untuk mengetahui seberapa besar pengaruh variabel customer experience yang terdiri dari dimensi comfort, educational, hedonic, novelty, recognized, relational, safety dan beauty terhadap revisit intention secara parsial. Dengan tingkat kepercayaan sebesar 95\%, 
besarnya pengaruh dapat dilihat dari nilai signifikansi, nilai $t_{\text {hitung }}$ dan nilai $t_{\text {tabel }}$. Berikut ini adalah kriteria pengujian dari Uji t.

1. Jika $t_{\text {sig }} \geq(\alpha=0,05)$ maka $\mathrm{H}_{0}$ diterima dan $\mathrm{H}_{1}$ ditolak, berarti variabel bebas customer experience yang terdiri dari dimensi comfort, educational, hedonic, novelty, recognized, relational, safety dan beauty secara parsial tidak berpengaruh pada variabel terikat revisit intention;

2. Jika $t_{\text {sig }} \leq(\alpha=0,05)$ maka $\mathrm{H}_{0}$ ditolak dan $\mathrm{H}_{1}$ diterima, berarti variabel bebas customer experience yang terdiri dari dimensi comfort, educational, hedonic, novelty, recognized, relational, safety dan beauty secara parsial berpengaruh terhadap variabel terikat revisit intention.

Berdasarkan hasil analisis data diketahui bahwa nilai signifikansi dari variabel bebas yang terdiri dari dimensi comfort, educational, hedonic, recognized, relational, safety dan beauty menunjukkan nilai signifikansi yang lebih besar dari $\alpha 0,05$. Selanjutnya nilai $\mathrm{t}_{\text {hitung }}$ dimensi ini memiliki nilai lebih kecil dari nilai $\mathrm{t}_{\text {tabel }}$ yaitu 1,657. Berdasarkan hasil tersebut dapat disimpulkan bahwa $\mathrm{H}_{0}$ diterima yang berarti tidak terdapat pengaruh secara parsial yang positif dan signifikan dimensi comfort, educational, hedonic, recognized, relational, safety dan beauty terhadap revisit intention (Y). Selanjutnya nilai signifikansi dari dimensi novelty menunjukkan nilai yang lebih besar dari $\alpha 0,05$ dan nilai $t_{\text {hitung dimensi novelty ini }}$ lebih besar dari nilai $\mathrm{t}_{\text {tabel }}$ yaitu 1,657. Berdasarkan hasil tersebut dapat disimpulkan bahwa $\mathrm{H}_{0}$ ditolak yang berarti terdapat pengaruh yang positif dan signifikan dimensi novelty terhadap revisit intention $(\mathrm{Y})$.

\section{Uji F (Uji Simultan)}

Uji $F$ dilakukan untuk mengetahui pengaruh variabel bebas terhadap variabel terikat secara bersama-sama. Uji $F$ dalam penelitian ini menggunakan tingkat keyakinan 95\% serta melakukan pengambilan keputusan berdasarkan nilai signifikansi, nilai $F_{\text {hitung }}$ dan nilai $\mathrm{F}_{\text {tabel. }}$ Kriteria pengujian dalam uji $\mathrm{F}$ adalah sebagai berikut.

1. Jika $F_{\text {sig }} \geq(\alpha=0,05)$ maka $H_{0}$ diterima dan $\mathrm{H}_{1}$ ditolak, hal ini berarti variabel bebas customer experience yang terdiri dari dimensi comfort, educational, hedonic, novelty, recognized, relational, safety dan beauty secara simultan tidak berpengaruh terhadap variabel terikat revisit intention (Y).

2. Jika $F_{\text {sig }} \leq(\alpha=0,05)$ maka $\mathrm{H}_{0}$ ditolak dan $\mathrm{H}_{1}$ diterima, hal ini berarti variabel bebas customer experience yang terdiri dari dimensi comfort, educational, hedonic, novelty, recognized, relational, safety dan beauty secara simultan berpengaruh terhadap variabel terikat revisit intention (Y).

Berdasarkan hasil statistik diketahui bahwa nilai signifikansi adalah sebesar 0,612 menunjukkan nilai yang lebih besar dari 0,05 . Selanjutnya $f_{\text {hitung }}$ memiliki nilai lebih kecil dari nilai $\mathrm{f}_{\text {tabel }}$ yaitu $0,791<2,013$. Hal ini berarti $\mathrm{H}_{0}$ diterima dan $\mathrm{H}_{1}$ ditolak, sehingga dapat disimpulkan bahwa tidak ada pengaruh yang positif dan signifikan secara simultan variabel bebas customer experience yang terdiri dari dimensi comfort, educational, hedonic, novelty, recognized, relational, safety dan beauty terhadap variabel terikat revisit intention.

\section{Pengaruh Dimensi Comfort terhadap Revisit Intention Wisatawan}

Berdasarkan hasil dari pengukuran persepsi sejumlah 135 wisatawan terhadap dimensi comfort, maka dapat diketahui bahwa wisatawan memberikan nilai tertinggi persepsinya pada indikator kenyamanan fasilitas pada paket wisata sepeda fun-tastic shuttle bike adventures. Hal ini menunjukkan bahwa fasilitas yang digunakan dalam kegiatan wisata sepeda memiliki kualitas yang baik sehingga mampu memberikan kenyamanan bagi wisatawan. Selanjunya, wisatawan memberikan persepsi lebih rendah terhadap indikator kenyamanan melakukan aktivitas wisata sepeda serta kenyamanan fasilitas pendukung yang digunakan pada saat aktivitas wisata sepeda fun-tastic shuttle bike adventures.

Hasil dalam penelitian ini menunjukkan bahwa dimensi comfort $\left(\mathrm{X}_{1}\right)$ tidak berpengaruh positif dan signifikan terhadap revisit intention wisatawan pengguna paket wisata sepeda funtastic shuttle bike adventures. Hal ini menunjukkan bahwa $\mathrm{H}_{0}$ diterima dan $\mathrm{H}_{1}$ ditolak. Nilai signifikansi dari dimensi comfort adalah sebesar 0,467 yang berarti lebih besar dari 0,05 serta nilai $t_{\text {hitung }}$ lebih kecil dari nilai $\mathrm{t}_{\text {tabel }}$ yaitu $0,729<1,657$. Dimensi comfort $\left(\mathrm{X}_{1}\right)$ mempunyai koefisien regresi positif dengan nilai 0,050 . Hal ini berarti setiap kenaikan 
dimensi comfort satu satuan dan variabel bebas yang lain konstan, maka mengakibatkan kenaikan variabel revisit intention (Y) sebesar 0,050 .

\section{Pengaruh Dimensi Educational terhadap Revisit Intention Wisatawan}

Berdasarkan hasil dari pengukuran persepsi sejumlah 135 wisatawan terhadap dimensi educational, maka dapat diketahui bahwa wisatawan memberikan nilai tertinggi persepsinya pada indikator keinginan untuk menggali pengetahuan lebih dalam pada saat melakukan aktivitas wisata sepeda fun-tastic shuttle bike adventures. Hal ini menunjukkan bahwa terdapat berbagai informasi yang belum diketahui wisatawan mengenai Desa Penglipuran dan paket wisata sepeda yang diikutinya sehingga wisatawan memiliki keinginan untuk menggali lebih banyak informasi. Selanjutnya, wisatawan memberikan persepsi lebih rendah terhadap indikator kemudahan mendapatkan informasi mengenai keberadaan paket wisata sepeda funtastic shuttle bike adventures karena media promosi dan penyebaran informasi terkait keberadaan paket wisata sepeda ini masih terbatas, hanya melalui brosur yang diberikan langsung oleh peneliti kepada wisatawan.

Hasil dalam penelitian ini menunjukkan bahwa dimensi educational $\left(\mathrm{X}_{2}\right)$ memiliki nilai signifikansi sebesar 0,780 menunjukkan nilai signifikansi lebih besar dari 0,05 . Selanjutnya nilai thitung dimensi educational adalah sebesar 0,280 yang berarti lebih kecil dari nilai $t_{\text {tabel }}$ yaitu 1,657. Berdasarkan hasil tersebut dapat disimpulkan bahwa $\mathrm{H}_{0}$ diterima yang berarti tidak terdapat pengaruh yang positif dan signifikan dimensi educational terhadap revisit intention $(\mathrm{Y})$. Hal ini diperkuat dengan hasil penelitian yang dilakukan oleh Yeni Yuniawati dan Ajeng Dewi (2016), yang menyatakan bahwa tidak terdapat pengaruh yang signifikan dimensi educational terhadap revisit intention. Dimensi educational $\left(\mathrm{X}_{2}\right)$ dalam penelitian ini, mempunyai koefisien regresi positif dengan nilai 0,023 . Hal ini berarti bahwa setiap kenaikan dimensi educational satu satuan dan variabel bebas yang lain konstan, maka mengakibatkan kenaikan variabel revisit intention $(\mathrm{Y})$ sebesar 0,023 .

\section{Pengaruh Dimensi Hedonic terhadap Revisit Intention Wisatawan}

Berdasarkan hasil dari pengukuran persepsi sejumlah 135 wisatawan terhadap dimensi hedonic, maka dapat diketahui bahwa wisatawan memberikan nilai tertinggi persepsinya pada indikator kesenangan pada saat melakukan aktivitas wisata sepeda funtastic shuttle bike adventures. Hal ini menunjukkan bahwa wisatawan memperoleh kesenangan dengan tingkat yang sangat baik pada saat mengikuti kegiatan wisata sepeda. Selanjunya, wisatawan memberikan persepsi lebih rendah terhadap indikator semangat dan kenangan yang didapatkan setelah mengikuti paket wisata sepeda fun-tastic shuttle bike adventures.

Hasil dalam penelitian ini menunjukkan bahwa dimensi hedonic $\left(\mathrm{X}_{3}\right)$ memiliki nilai signifikansi sebesar 0,981. Hal ini menunjukkan nilai signifikansinya lebih besar dari 0,05 . Selanjutnya nilai $t_{\text {hitung }}$ dimensi hedonic adalah sebesar 0,024 yang berarti lebih kecil dari nilai $t_{\text {tabel }}$ yaitu 1,657. Berdasarkan hasil tersebut dapat disimpulkan bahwa $\mathrm{H}_{0}$ diterima yang berarti tidak terdapat pengaruh yang positif dan signifikan dimensi hedonic terhadap revisit intention (Y). Dimensi hedonic $\left(\mathrm{X}_{3}\right)$ mempunyai koefisien regresi positif dengan nilai 0,002 . Hal ini berarti setiap kenaikan dimensi hedonic satu satuan dan variabel bebas yang lain konstan, maka mengakibatkan kenaikan variabel revisit intention (Y) sebesar 0,002 .

\section{Pengaruh Dimensi Novelty terhadap Revisit Intention Wisatawan}

Berdasarkan hasil dari pengukuran persepsi sejumlah 135 wisatawan terhadap dimensi novelty, maka dapat diketahui bahwa wisatawan memberikan nilai tertinggi persepsinya pada indikator tingkat perubahan aktivitas pada saat melakukan aktivitas wisata sepeda fun-tastic shuttle bike adventures. Selanjutnya, wisatawan memberikan persepsi lebih rendah terhadap indikator pengalaman baru yang didapatkan setelah mengikuti paket wisata sepeda fun-tastic shuttle bike adventures.

Hasil dalam penelitian ini menunjukkan dimensi novelty memiliki nilai signifikansi sebesar 0,040. Hal ini menunjukkan nilai signifikansinya lebih kecil dari 0,05. Selanjutnya nilai $t_{\text {hitung }}$ dimensi novelty adalah sebesar 2,078 yang berarti lebih besar dari 
nilai $t_{\text {tabel }}$ yaitu 1,657. Berdasarkan hasil tersebut dapat disimpulkan bahwa $\mathrm{H}_{1}$ diterima yang berarti terdapat pengaruh yang positif dan signifikan dimensi novelty terhadap revisit intention (Y). Hal ini diperkuat dengan hasil penelitian dari Yeni Yuniawati dan Ajeng Dewi (2016) yang menyatakan bahwa terdapat pengaruh yang positif dan signifikan dimensi novelty terhadap variabel revisit intention. Dimensi novelty $\left(\mathrm{X}_{4}\right)$ dalam penelitian ini, mempunyai koefisien regresi positif dengan nilai 0,147 . Hal ini berarti setiap kenaikan dimensi novelty satu satuan dan variabel bebas yang lain konstan, maka mengakibatkan kenaikan variabel revisit intention (Y) sebesar 0,147 .

\section{Pengaruh Dimensi Recognized terhadap Revisit Intention Wisatawan}

Berdasarkan hasil dari pengukuran persepsi sejumlah 135 wisatawan terhadap dimensi recognized, maka dapat diketahui bahwa wisatawan memberikan nilai tertinggi persepsinya pada indikator keramahan pramuwisata dalam menerima wisatawan pada wisata sepeda fun-tastic shuttle bike adventures. Selanjutnya, wisatawan memberikan persepsi lebih rendah terhadap indikator kualitas pelayanan dan kemudahan mendapatkan informasi dari pramuwisata pada paket wisata sepeda fun-tastic shuttle bike adventures.

Hasil dalam penelitian ini menunjukkan dimensi recognized memiliki nilai signifikansi sebesar 0,926. Hal ini menunjukkan nilai signifikansinya lebih besar dari 0,05. Selanjutnya nilai $t_{\text {hitung }}$ dimensi recognized adalah sebesar -0,093 yang berarti lebih kecil dari nilai $t_{\text {tabel }}$ yaitu 1,657. Berdasarkan hasil tersebut dapat disimpulkan bahwa $\mathrm{H}_{0}$ diterima yang berarti tidak terdapat pengaruh yang positif dan signifikan dimensi recognized terhadap revisit intention (Y). Dimensi recognized $\left(\mathrm{X}_{5}\right)$ mempunyai koefisien regresi negatif dengan nilai sebesar $-0,012$. Hal ini berarti setiap kenaikan dimensi recognized satu satuan dan variabel bebas yang lain konstan, maka mengakibatkan penurunan variabel revisit intention (Y) sebesar 0,012.

\section{Pengaruh Dimensi Relational terhadap Revisit Intention Wisatawan}

Berdasarkan hasil dari pengukuran persepsi sejumlah 135 wisatawan terhadap dimensi relational, maka dapat diketahui bahwa wisatawan memberikan nilai tertinggi persepsinya pada indikator kesediaan pramuwisata menghargai budaya wisatawan pada wisata sepeda fun-tastic shuttle bike adventures. Selanjutnya, wisatawan memberikan persepsi lebih rendah terhadap indikator antusias pramuwisata menerima wisatawan pada wisata sepeda fun-tastic shuttle bike adventures.

Hasil dalam penelitian ini menunjukkan bahwa dimensi relational memiliki nilai signifikansi sebesar 0,864. Hal ini menunjukkan nilai signifikansinya lebih besar dari 0,05 . Selanjutnya nilai $t_{\text {hitung dimensi }}$ relational adalah sebesar $-0,172$ yang berarti lebih kecil dari nilai tabel yaitu 1,657. Berdasarkan hasil tersebut dapat disimpulkan bahwa $\mathrm{H}_{0}$ diterima yang berarti tidak terdapat pengaruh yang positif dan signifikan dimensi relational terhadap revisit intention (Y). Dimensi relational $\left(\mathrm{X}_{6}\right)$ mempunyai koefisien regresi negatif dengan nilai sebesar -0,016. Hal ini berarti setiap kenaikan dimensi relational satu satuan dan variabel bebas yang lain konstan, maka mengakibatkan penurunan variabel revisit intention (Y) sebesar 0,016 .

\section{Pengaruh Dimensi Safety terhadap Revisit Intention Wisatawan}

Berdasarkan hasil dari pengukuran persepsi sejumlah 135 wisatawan terhadap dimensi safety, maka dapat diketahui bahwa wisatawan memberikan nilai tertinggi persepsinya pada indikator keamanan dari kejahatan pada saat melakukan aktivitas wisata sepeda fun-tastic shuttle bike adventures. Selanjutnya, wisatawan memberikan persepsi lebih rendah terhadap indikator keamanan akses pada wisata sepeda fun-tastic shuttle bike adventures. Hal ini dikarenakan akses jalan yang dilalui pada saat aktivitas wisata sepeda fun-tastic shuttle bike adventures di beberapa bagian mengalami kerusakan.

Hasil dalam penelitian ini menunjukkan bahwa dimensi safety memiliki nilai signifikansi sebesar 0,577. Hal ini menunjukkan nilai signifikansinya lebih besar dari 0,05 . Selanjutnya nilai $t_{\text {hitung }}$ dimensi safety adalah sebesar $-0,559$ yang berarti lebih kecil dari nilai $t_{\text {tabel }}$ yaitu 1,657. Berdasarkan hasil tersebut dapat disimpulkan bahwa $\mathrm{H}_{0}$ diterima yang berarti tidak terdapat pengaruh yang positif dan signifikan dimensi safety terhadap revisit intention (Y). Hal ini diperkuat dengan hasil penelitian yang 
dilakukan oleh Yeni Yuniawati dan Ajeng Dewi (2016) yang menyatakan bahwa dimensi safety tidak berpengaruh signifikan terhadap variabel revisit intention. Dimensi safety $\left(\mathrm{X}_{7}\right)$ mempunyai koefisien regresi negatif dengan nilai $-0,044$. Hal ini berarti setiap kenaikan dimensi safety satu satuan dan variabel bebas yang lain konstan, maka mengakibatkan penurunan variabel revisit intention $(\mathrm{Y})$ sebesar 0,044 .

\section{Pengaruh Dimensi Beauty terhadap Revisit Intention Wisatawan}

Berdasarkan hasil dari pengukuran persepsi sejumlah 135 wisatawan terhadap dimensi beauty, maka dapat diketahui bahwa wisatawan memberikan nilai tertinggi persepsinya pada indikator tingkat keindahan alam yang terdapat pada aktivitas wisata sepeda fun-tastic shuttle bike adventures. Selanjutnya, wisatawan memberikan persepsi lebih rendah terhadap indikator keindahan daya tarik wisata buatan pada paket wisata sepeda fun-tastic shuttle bike adventures.

Hasil dari penelitian ini menunjukkan bahwa dimensi beauty memiliki nilai signifikansi sebesar 0,807. Hal ini menunjukkan nilai signifikansinya lebih besar dari 0,05 . Selanjutnya nilai $t_{\text {hitung }}$ dimensi beauty adalah sebesar -0,245 yang berarti lebih kecil dari nilai tabel yaitu 1,657. Berdasarkan hasil tersebut dapat disimpulkan bahwa $\mathrm{H}_{0}$ diterima yang berarti tidak terdapat pengaruh yang positif dan signifikan dimensi beauty terhadap revisit intention $(\mathrm{Y})$. Dimensi beauty $\left(\mathrm{X}_{8}\right)$ mempunyai koefisien regresi negatif dengan nilai $-0,019$. Hal ini berarti setiap kenaikan dimensi beauty satu satuan dan variabel bebas yang lain konstan, maka mengakibatkan penurunan variabel revisit intention $(\mathrm{Y})$ sebesar 0,019 .

\section{Pengaruh Customer Experience terhadap Revisit Intention Wisatawan}

Hasil dari penelitian ini menunjukkan bahwa kontribusi secara simultan hubungan antara variabel customer experience yang terdiri dari dimensi comfort, educational, hedonic, novelty, recognized, relational, safety dan beauty terhadap revisit intention adalah sebesar $17,6 \%$ sedangkan sisanya sebesar $82,4 \%$ dipengaruhi oleh faktor lain yang tidak diteliti dalam penelitian ini.

Berdasarkan beberapa hasil penelitian terdahulu, revisit intention dapat dipengaruhi oleh berbagai faktor lain misalnya personal involment, kepuasan dan place attachment (Renza Fahlevi, 2016). Personal involment menunjukkan keterlibatan wisatawan pada aktivitas wisata sehingga memberikan kesan positif yang dapat membuat adanya niat wisatawan untuk berkunjung kembali. Selain personal involment, faktor kepuasan juga dapat mempengaruhi niat berkunjung kembali wisatawan. Kepuasan terjadi ketika wisatawan mendapatkan hal sesuai atau melebihi ekspektasi wisatawan. Selanjutnya faktor place attachment dijelaskan pula sebagai salah satu hal yang dapat mempengaruhi revisit intention karena dengan adanya keterikatan wisatawan dengan suatu daerah wisata maka menimbulkan niat untuk berkunjung kembali (Renza Fahlevi, 2016).

Selanjutnya hasil penelitian menurut Wiratini (2018) menyebutkan bahwa faktor daya tarik wisata, kualitas pelayanan, fasilitas dan kepuasan wisatawan juga merupakan faktor yang dapat mempengaruhi revisit intention. Hal ini juga diperkuat oleh temuan dari penelitian Kuntjara (2007) dan Kusuma Adhi (2009) yang menyatakan bahwa revisit intention dapat dipengaruhi oleh faktor kualitas pelayanan. Selanjutnya, hasil penelitian dari Bellinda (2014) juga menyatakan bahwa kualitas pelayanan berpengaruh secara positif dan signifikan terhadap revisit intention. Menurut hasil penelitian dari Bellinda (2014) ini, kualitas pelayanan memberikan kontribusi sebesar 54\% terhadap niat berkunjung kembali. Kegiatan promosi dan citra wisata juga menjadi faktor yang mempengaruhi minat wisatawan untuk melakukan kunjungan kembali (Bellinda, 2014).

Beberapa hasil penelitian sebelumnya terkait pengaruh customer experience terhadap revisit intention, diantaranya hasil penelitian oleh Yeni Yuniawati dan Ajeng Dewi (2016) dan hasil penelitian oleh Cynthia Asrivionny dan Yeni Yuniawati (2015) menyatakan bahwa variabel customer experience memberikan pengaruh yang positif dan signifikan terhadap revisit intention. Selanjutnya hasil penelitian yang dilakukan oleh Klara Noviantika dan Edriana Pangestuti (2017) menyatakan bahwa variabel revisit intention dapat dijelaskan oleh variabel customer experience sebesar 51,2\%. Hasil penelitian yang dilakukan penulis berbeda dengan beberapa hasil penelitian terdahulu 
dikarenakan subjek yang diteliti berupa eksperimen dan merupakan hal yang baru, sehingga ditemukan pula hasil penelitian baru.

Berdasarkan pemaparan di atas, dapat disimpulkan bahwa revisit intention dapat dijelaskan oleh variabel customer experience yang terdiri dari dimensi comfort, educational, hedonic, novelty, recognized, relational, safety dan beauty sebesar 17,6\% sedangkan sisanya sebesar $82,4 \%$ dipengaruhi oleh faktor lain yaitu faktor kepuasan, kualitas pelayanan, personal involment, place attachment, promosi dan citra wisata serta daya tarik wisata.

\section{SIMPULAN DAN SARAN Simpulan}

Berdasarkan hasil pengujian secara parsial (Uji t) menunjukkan hasil sebagai berikut dimensi comfort tidak memberikan pengaruh yang positif dan signifikan terhadap revisit intention; dimensi educational tidak memberikan pengaruh yang positif dan signifikan terhadap revisit intention; dimensi hedonic tidak memberikan pengaruh yang positif dan signifikan terhadap revisit intention; dimensi novelty berpengaruh positif dan signifikan terhadap revisit intention; dimensi recognized tidak memberikan pengaruh yang positif dan signifikan terhadap revisit intention; dimensi relational tidak memberikan pengaruh yang positif dan signifikan terhadap revisit intention; dimensi safety tidak memberikan pengaruh yang positif dan signifikan terhadap revisit intention; dan dimensi beauty tidak memberikan pengaruh yang positif dan signifikan terhadap revisit intention.

Berdasarkan hasil pengujian secara simultan (uji F) menunjukan hasil bahwa tidak ada pengaruh yang positif dan signifikan variabel bebas customer experience yang terdiri dari dimensi comfort, educational, hedonic, novelty, recognized, relational, safety dan beauty terhadap variabel terikat revisit intention. Customer experience secara simultan hanya dapat menjelaskan revisit intention sebesar $17,6 \%$, sedangkan sisanya sebesar $82,4 \%$ dijelaskan oleh faktor lain yang tidak diteliti dalam penelitian ini.

\section{Saran}

Saran akademis ditujukan bagi mahasiswa atau kalangan masyarakat ilmiah yang melakukan penelitian berikutnya. Penelitian ini masih terbatas pada variabel customer experience, maka disarankan untuk peneliti berikutnya untuk meneliti variabel lain seperti kepuasan wisatawan (customer satisfaction), kualitas layanan (service quality), dan variabel strategi promosi. Penelitian terhadap variabel-variabel tersebut akan melengkapi penelitian ini serta membuat pengembangan paket wisata sepeda "FunTastic Shuttle Bike Adventures" lebih komprehensif.

Penelitian ini menunjukkan hasil bahwa variabel novelty (kebaruan) memberikan pengaruh yang positif dan signifikan terhadap revisit intention. Kebaruan yang dimaksud adalah keanekaragaman aktivitas yang bisa diikuti wisatawan saat berkunjung. Maka penulis memberikan rekomendasi untuk menambah aktivitas atau pelayanan sehingga wisatawan merasakan perubahan aktivitas yang tidak monoton, mendapat pengalaman baru dan merasakan keunikan aktivitas saat berwisata sehingga niat berkunjung kembali (revisit intention) wisatawan meningkat. 


\section{Kepustakaan}

Hslen Lin, Chung. 2012. Effects of Authenticity Perception, Hedonics, and Perceived Value on Ceramic Souvenir Repurchasing Intention. Journal of Travel \& Tourism Marketing. Vol. 29, No. 8.

Yuniawati, Yeni Finardi dan Indriyani, Ajeng Dewi. 2016. Pengaruh Customer Experience terhadap Revisit Intention di Taman Wisata Alam Gunung Tangkuban Perahu. Tourism and Hospitality Essentials (THE) Journal. Vol. 6, No. 1.

Asrivionny, Cynthia dan Yuniawati, Yeni. 2015. Pengaruh Customer Experience terhadap Revisit Intention di The Trans Luxury Hotel Bandung. Tourism and Hospitality Essentials (THE) Journal. Vol. 5, No. 1.

Ardana, I Cenik dan Hendro, Lukman. 2016. Sistem Informasi Akuntansi. Jakarta: Mitra Wacana Media.

Kiswati, Sri. 2010. Studi tentang Sikap Konsumen atas Merek Tolak Angin pada Mahasiswi FE Undip Semarang. Tesis Program Studi Magister
Manajemen Universitas Diponegoro Semarang.

Kuntjara. 2007. Analisis Faktor-Faktor yang Mempengaruhi Minat Beli Ulang Konsumen. Tesis Magister Manajemen Universitas Diponegoro Semarang.

Adhi, Rah Kusuma. 2009. Pengaruh Kualitas Pelayanan, Kompetensi Tenaga Penjual, dan Citra Perusahaan terhadap Minat Beli Ulang. Tesis Magister Manajemen Universitas Diponegoro Semarang.

Bellinda, Nuraeni Sofia. 2014. Analisis Faktor yang Mempengaruhi Minat Kunjungan Ulang Wisatawan Semarang. Jurnal Bisnis Strategi Manajemen. Vol. 23, No. 1.

Noviantika, Klara. 2017. Pengaruh Customer Experience terhadap Kepuasan dan Dampaknya pada Minat untuk Berkunjung Kembali pada Kusuma Agrowisata Kota Batu. Jurnal Administrasi Bisnis. Vol. 50, No. 6. 